IRA-International Journal of Applied Sciences ISSN 2455-4499; Vol.08, Issue 02 (August 2017)

Pg. no. $48-54$

Institute of Research Advances

https://research-advances.org/index.php/IRAJAS

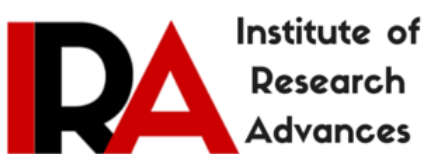

\title{
Determination of Some Physical Properties of Dried Jujube Fruit
}

\author{
Mansoureh Pourjafar \\ Higher Educational Complex of Saravan, Saravan, Sistan and Baluchestan, Iran.
}

Type of Review: Peer Reviewed.

DOI: http://dx.doi.org/10.21013/jas.v8.n2.p1

\section{How to cite this paper:}

Pourjafar, M. (2017). Determination of Some Physical Properties of Dried Jujube Fruit. IRA International Journal of Applied Sciences (ISSN 2455-4499), 8(2), 48-54. doi:http://dx.doi.org/10.21013/jas.v8.n2.p1

(C) Institute of Research Advances.

\section{(cc)) BY-NC}

This work is licensed under a Creative Commons Attribution-Non Commercial 4.0 International License subject to proper citation to the publication source of the work.

Disclaimer: The scholarly papers as reviewed and published by the Institute of Research Advances (IRA) are the views and opinions of their respective authors and are not the views or opinions of the IRA. The IRA disclaims of any harm or loss caused due to the published content to any party.

Institute of Research Advances is an institutional publisher member of Publishers Inter Linking Association Inc. (PILA-CrossRef), USA. The institute is an institutional signatory to the Budapest Open Access Initiative, Hungary advocating the open access of scientific and scholarly knowledge. The Institute is a registered content provider under Open Access Initiative Protocol for Metadata Harvesting (OAI-PMH).

The journal is indexed \& included in CAS Source Index of Chemical Abstracts Service of American Chemical Society (USA), WorldCat Discovery Service (USA), CrossRef Metadata Search (USA), WorldCat (USA), OCLC (USA), Open J-Gate (India), EZB (Germany) Scilit (Switzerland), Airiti (China), Bielefeld Academic Search Engine (BASE) of Bielefeld University, Germany, PKP Index of Simon Fraser University, Canada. 


\begin{abstract}
Some physical properties of Iranian Jujube fruit were evaluated. Jujube fruit samples mean values of length, width, thickness were found as $18.005 \mathrm{~mm}, 14.96 \mathrm{~mm}, 15.26 \mathrm{~mm}$. Arithmetic mean diameter, geometric mean diameter were found as $16.08 \mathrm{~mm}, 16.01$ respectively and surface area, Sphericity, porosity, mass, volume, bulk density and true density were also found as: $805.65 \mathrm{~mm}^{2}, 89 \%, 77.2 \%, 1.45 \mathrm{gr}, 2.61 \mathrm{~cm}^{3}, 0.23 \mathrm{gr} \mathrm{cm}^{-3}$, $0.55 \mathrm{gr} \mathrm{cm}^{-3}$ respectively. Projected area perpendicular to length, width and thickness were measured as, $152.03 \mathrm{~mm}^{2}, 220.02 \mathrm{~mm}^{2}, 271.4 \mathrm{~mm}^{2}$ respectively. With comparison between friction coefficients on different surface for Jujube fruit. The results showed that the static coefficient of friction was more than dynamic coefficient of friction.The tests done on the galvanized steel surface, plywood and glass surface. The most coefficient of friction was found on the plywood surface and the least coefficient of friction was measured on the glass surface.
\end{abstract}

Keywords: Jujube fruit, Physical properties, Engineering parameters, geometric parameters.

\title{
Introduction
}

Ziziphusjujuba, commonly called jujube, this plant usually grown in tropical and sub-tropical regions in the world [19].It is a small deciduous tree or shrub reaching a height of 5-12 metres, usually with thorny branches. The leaves are shiny-green, ovate-acute, 2-7 centimetres long and 1-3 centimetres wide, with three conspicuous veins at the base, and a finely toothed margin. The fruit is an edible oval drupe 1.5-3 centimetres deep ( Figure1). Its precise natural distribution is uncertain due to extensive cultivation, but is thought to be in southern Asia, between Lebanon, northern India, and southern and central China, and possibly also southeastern Europe though more likely introduced there [24].To develop appropriate equipment for harvesting, handling, conveying cleaning, delivering, separating, packing, storing, drying and processing of agricultural products, the detailed knowledge of physical properties of crops are essential [8].Some physical properties have been studied for various agricultural products fruits and crops by other researchers such as cocoa bean [4], plum [11], soybean [16], Jatrophacurcas L. fruits, nuts and kernels [27]pigeon pea [26], olive cultivars[21], wheat [30], caperfruit (Capparisspp) [25], nutmeg [5],watermelon seed[15], pistachio nut and its kernel [23], and palm fruit, kernel and nut [9]. Size and shape of potato tubers [29] determined the physical properties of common varieties of Iranian grown potatoes and the relationships among their physical characteristics [31] compared several properties of four orange varieties. [28] used 11 models for predicting mass of apples based on geometrical features [2].Determined some physical properties of African oil bean seeds to obtaining relevant data for the design of tools, equipment, machines and systems for their processing[13].

Objectives of this study is to determine some physical properties of dried Jujube Fruit in order to facilitate the design of some machines for its processing.

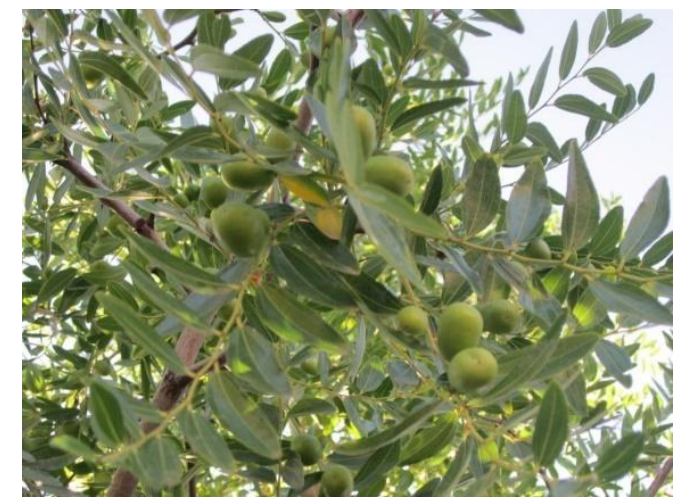

Figure 1: Location of the fruit on the tree 


\section{MATERIALS AND METHODS}

In this study, about $5 \mathrm{~kg}$ dried jujube fruits were prepared from local markets in southern Khorasan region in Iran.Then100 Jujube fruits were selected randomly and transported to the physical laboratory for measurement of some physical properties (Figure2).The initial moisture content determined through an oven method at $105 \pm 30 \mathrm{C}$ during 24 hours [6].

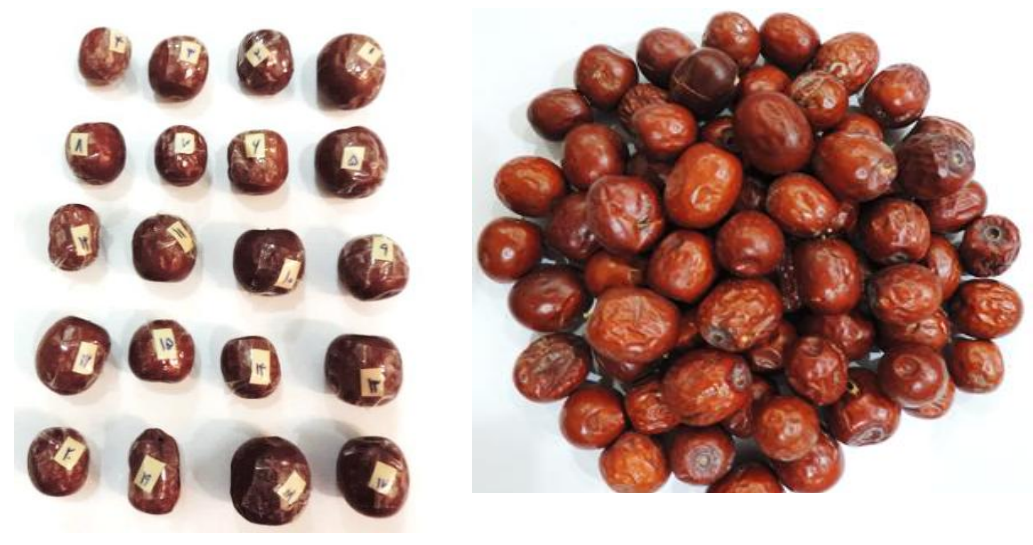

Figure 2: samples of dried Jujube Fruit

For measurement the length (L), width (W) and thickness $(\mathrm{T})$, the samples were using a digital caliper with an accuracy of $0.02 \mathrm{~mm}$ and for measurement mass samples were using a digital Balance with an accuracy of $0.01 \mathrm{gr}$.

The geometric mean diameter (Dg), arithmetic mean diameter (Da) porosity (packing factor), bulk density, Sphericity (f), surface area (S) of the varieties were calculated using the formula given by (Mohsenin.,1986). The arithmetic mean diameter (AMD), and geometric mean diameter (GMD), were calculated using expressions given by $[2,18]$. The volume of fruit for the samples were calculated using the expression given by [18]. The true density was determined using toluene displacement method [3]. The porosity was computed from the values of the true and bulk density of samples by using the relationship given by [12]. The static coefficients of friction were obtained with respect to three surfaces of glass, plywood and galvanized steel. The experiment was done by using an inclined plane device as described by [10]. The inclined plane was gently raised and the angle of inclination at which the sample started sliding was read off the protractor with sensitivity of one degree. The tangent of the angle was reported as the coefficient of friction [12].

Projected areas were determined by image processing method. To obtain projected areas, WinArea_UT_08 system [17] was used Captured images from the camera are transmitted to the computer card which works as an analog to digital converter. Digital images are then processed in the software and the desired user needs are determined. Total error for those objects was less than $1.5 \%$. This method have been used and reported by several researchers $[22,13,14]$. The results are shown in Table 1 . Regression analysis was carried out using Microsoft Excel 2007 software to determine the relationship between mass and other physical properties.

\section{RESULTS AND DISCUSSION}

The average moisture content of jujube fruit samples was found to be $15.5 \%$. Results showed that mass varied from 0.88 to $1.86 \mathrm{gr}$ and dimensions varied from length 15 to $20.7 \mathrm{~mm}$, width 13.6 to $17 \mathrm{~mm}$ and thickness 13.9 to 17.6 respectively. The arithmetic and geometric mean diameter, varied from 14.17 to $18.43 \mathrm{~mm}$ and 14.15 to $18.36 \mathrm{~mm}$ respectively. Sphericity and surface area were $89 \%$ to $94 \%$, and 629.06 to $1058.97 \mathrm{~mm}^{2}$ respectively. The averages of the tri-axial dimensions of the fruits are given in Tables 1 . The average projected areas perpendicular to length, width, and thickness were obtained as $152.03 \mathrm{~mm}^{2}$, $220.02 \mathrm{~mm}^{2}, 271.4 \mathrm{~mm}^{2}$ respectively. The average values of true density, bulk density and porosity were found as $0.55 \mathrm{~g} / \mathrm{cm}^{3}, 0.23 \mathrm{~g} / \mathrm{cm}^{3}$ and $77.2 \%$ respectively. Mean coefficient of static on plywood, galvanized steel and glass surfaces, were found as $0.37,0.35$ and 0.31 respectively. Also mean coefficient of dynamic 
on plywood, galvanized steel and glass surfaces, were found as $0.34,0.32$ and 0.27 respectively. Results showed that the static, and dynamic coefficient of friction for jujube on plywood surface were higher than galvanized steel and glass surfaces.

Table 1: Some physical parameters of jujube fruit

\begin{tabular}{|c|c|c|c|}
\hline Properties (jujube) & Min & Max & Mean \\
\hline Length $(\mathrm{mm})$ & 15 & 20.7 & 18.005 \\
\hline Width(mm) & 13.6 & 17 & 14.956 \\
\hline Thickness(mm) & 13.9 & 17.6 & 15.262 \\
\hline $\begin{array}{l}\text { Projected area } \\
\text { perpendicular to } \mathrm{L}\left(\mathrm{mm}^{2}\right)\end{array}$ & 150 & 154.02 & 152.03 \\
\hline $\begin{array}{l}\text { Projected area } \\
\text { perpendicular to } \mathrm{W}\left(\mathrm{mm}^{2}\right)\end{array}$ & 217.03 & 223 & 220.02 \\
\hline $\begin{array}{l}\text { Projected area } \\
\text { perpendicular to } \mathrm{T}\left(\mathrm{mm}^{2}\right)\end{array}$ & 268.3 & 273.3 & 271.4 \\
\hline $\begin{array}{l}\text { Arithmetic } \\
\text { diameter }(\mathrm{mm})\end{array}$ & 14.16 & 18.43 & 16.08 \\
\hline Geometric mean diameter $(\mathrm{mm})$ & 14.15 & 18.36 & 16.01 \\
\hline Sphericity (\%) & 85 & 95 & \\
\hline Surface area $\left(\mathrm{mm}^{2}\right)$ & 629.06 & 1058.97 & 805.65 \\
\hline Porosity (\%) & 72.2 & 82.3 & 77.2 \\
\hline Mass (gr) & 0.88 & 2.12 & 1.45 \\
\hline Volume $\left(\mathrm{cm}^{3}\right)$ & 2 & 3.5 & 2.61 \\
\hline Bulk density $\left(\mathrm{grcm}^{-3}\right)$ & 0.18 & 0.28 & 0.23 \\
\hline True density $\left(\mathrm{grcm}^{-3}\right)$ & 0.41 & 0.62 & 0.55 \\
\hline \multicolumn{4}{|l|}{ Static coefficient of friction: } \\
\hline Plywood & 0.29 & 0.39 & 0.37 \\
\hline Galvanized iron & 0.29 & 0.38 & 0.35 \\
\hline Glass surface & 0.25 & 0.36 & 0.31 \\
\hline
\end{tabular}

Regression equations and correlation of coefficient of Jujube fruit mass model based on the length, width, thickness, arithmetic mean diameter, geometric mean diameter and volume are drawn in Figure3.

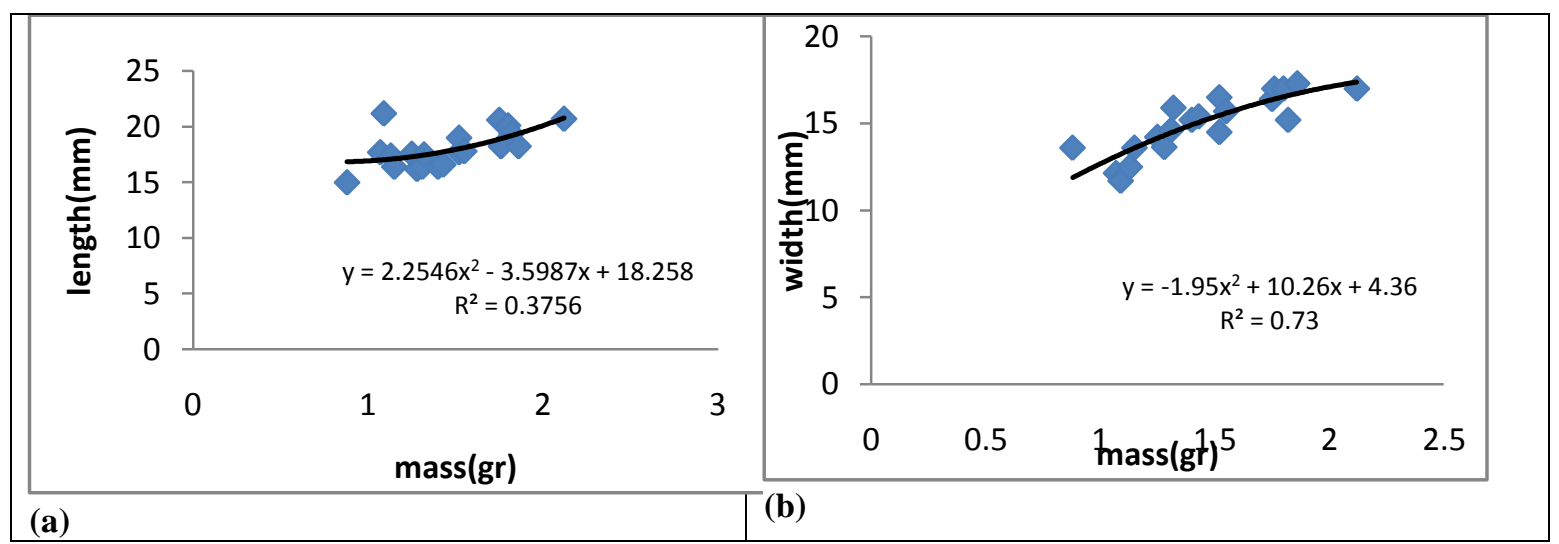




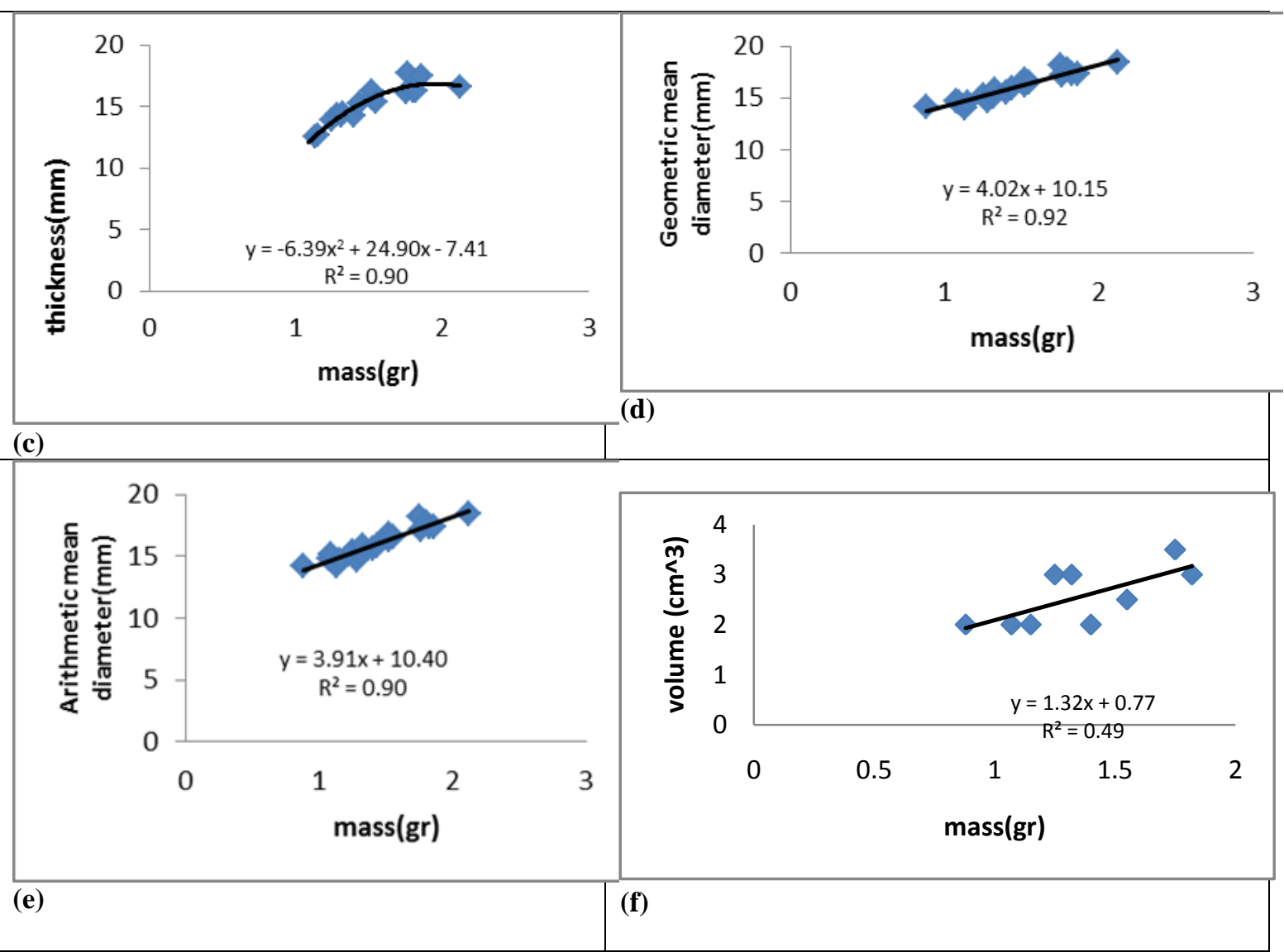

Figure 3: Jujube length, width, thickness, Arithmetic mean diameter, Geometric mean diameter and volume model based on the mass

According to the graphs plotted in Figure 3 and regression equations, we conclude that the highest correlation coefficient was between the geometric mean diameter by the mass (0.92) and the lowest correlation coefficient was between the lengths by the mass $(0.38)$.

Table 2: Regression equations and correlation coefficient $\left(R^{2}\right)$

\begin{tabular}{lll}
\hline & Regression equations & correlation coefficient $\left(R^{2}\right)$ \\
\hline Relation between length and mass & $\mathrm{L}=2.25 \mathrm{~m}^{2}-3.59 \mathrm{~m}+18.26$ & 0.38 \\
Relation between width and mass & $\mathrm{W}=-1.95 \mathrm{~m}^{2}+10.26 \mathrm{~m}+4.36$ & 0.73 \\
Relation between thickness and & $\mathrm{T}=-6.39 \mathrm{~m}^{2}+24.90 \mathrm{~m}-7.41$ & 0.90 \\
mass & & 0.90 \\
$\begin{array}{l}\text { Relation between Arithmetic } \\
\text { mean diameter and mass }\end{array}$ & $\mathrm{Da}=3.91 \mathrm{~m}+10.40$ & 0.92 \\
$\begin{array}{l}\text { Relation between Geometric } \\
\text { mean diameter and mass }\end{array}$ & $\mathrm{Dg}=4.02 \mathrm{~m}+10.15$ & 0.49 \\
$\begin{array}{l}\text { Relation between volume and } \\
\text { mass }\end{array}$ & $\mathrm{V}=$ \\
\hline
\end{tabular}




\section{CONCLUSION}

Some physical properties of dried Jujube Fruit were determined by several equipments. The following results are the most important. Mean values of Length, Width, Thickness, Projected area perpendicular to length, width and thickness were found as, $18.005 \mathrm{~mm}, 14.96 \mathrm{~mm}, 15.26 \mathrm{~mm}, 152.03 \mathrm{~mm}^{2}, 220.02 \mathrm{~mm}^{2}$, $271.4 \mathrm{~mm}^{2}$ respectively. Arithmetic mean diameter, Geometric mean diameter were $16.08 \mathrm{~mm}, 16.01$ respectively and surface area, sphericity, Porosity, mass, volume, bulk density and true density were found as: $805.65 \mathrm{~mm}^{2}, 89 \%, 77.2 \%, 1.45 \mathrm{gr}, 2.61 \mathrm{~cm}^{3}, 0.23 \mathrm{gr} \mathrm{cm}^{-3}, 0.55 \mathrm{gr} \mathrm{cm}^{-3}$ respectively. Mean Values of coefficient of static friction on plywood, galvanized steel, and glass surfaces were obtained as $0.37,0.35$ and 0.31 , respectively. Mean values of coefficient of dynamic friction on plywood, galvanized steel, and glass surfaces were obtained as $0.34,0.32$ and 0.27 , respectively. Most of the coefficient of friction was on the plywood surface and least of the coefficient of friction was on the glass surface. The most correlation of coefficient was found between geometric mean diameter and mass (0.92).

\section{References}

[1] Akbolat D, C Ertekin, and HO Menges, 2008. Physical and nutritional properties of jujube (Zizyphusjujuba Mill.) growing in Turkey. Asian Journal of Chemistry 20 : 757-766.

[2] Asoegwu, SN, SO Ohanyere, OP Kanu and CN Iwueke, 2006. Physical properties of African oil bean seed (Pentaclethramacrophylla), Agric. Eng. Int, , the CIGR Ejournal FP 05006.

[3] Bagherpour H, S Minaei and MH Khoshtaghaza, 2010. Selected physico-mechanical properties of lentil seed, Int. Agrophys, 24, 81-84.

[4] Bart-Plange A and EA Baryeh, 2003. Physical properties of category B cocoa beans, J. Food Eng, , 60, 219-227.

[5] Burubai W, AJ Akor, AH Igoni and YT Puyate, 2007. Some physical properties of African nutmeg (Monodoramyristica). Int. Agrophysics, , 21, 123-126.

[6] Correa PC, DA Schwanz, F Silva, C Jaren, PC Afonso Junior and I Arana, 2007. Physical and mechanical properties in rice processing. J. Food Eng., 79, 137-142.

[7] Corrêa, PC, F Schwanz da Silva, C Jaren, PC AfonsoJúnior and I Arana, 2007 Physical and mechanical properties in rice processing, J. Food Eng., vol. 79, pp. 137-142,.

[8] Davies RM and AMI EI-Okene, 2009. Moisture-dependent physical properties of soybean, Int. Agrophysics., ,23(3), 299-303.

[9] Davies RM, 2012. Physical and mechanical properties of palm fruit, kernel and nut, J.Agric. Tech, , 8(7), 2147-2156.

[10] Dutta SK, VKNema and RK Bhardwaj, 1988. Physical properties of gram, J. Agric. Eng. Res, , 39, 259- 268.

[11] Ertekin S, O Gozlekci, S Kabas, Sonmez and I Akinci, 2006, Some physical, pomological and nutritional properties of two plum (Prunusdomestica L.) cultivars, J. Food Eng, , 75, 508-514.

[12] GharibzahediSMT, V Etemad and J Mirarab, 2010. Study on some engineering attributes of pine nut (Pinuspinea) to the design of processing equipment, Res. Agr. Eng, , 56(3), 99-106.

[13] Kermat Jahromi M, S Rafiee, AJafari and A Tabatabaeefar, 2007. Determination of dimension and area properties of date (Barhi) by image analysis, International Conference on Agricultural, Food and Biological Engineering and Post-Harvest Production Technology, KhonKaen, 21-24 January, Thailand.

[14] Khoshnam F, A Tabatabaeefar, M Ghasemi and ABorghei, 2007. Mass modeling of pomegranate (Punicagranatum L.) fruit with some physical characteristics, ScientiaHorticulturae, 114, 21-26.

[15] Koocheki A, SMA Razavi, E Milani, TM Moghadan, M Abedini and S Alamatiyan, 2007. Physical properties of watermelon seed as a function of moisture content and variety, Int. Agrophysics, vol. 21: pp. 349-359.

[16] Manuwa SI and GGAfuye, 2004. Moisture dependent physical properties of soyabean (Var-TGx 1871-5E), Nigeria J. Industrial Studies., , 3(2), 45-54.

[17] Mirasheh R, 2006. Designing and making procedure for a machine determining olive image dimensions, Master of Science Thesis, Tehran University.

[18] Mohsenin NN, 1986. Physical properties of Plant and Animal Materials, 2nd edition (revised). 2nd Ed.; Gordon \& Breach Science Publishers, New York. 
[19] Mukhtar HM, SH Ansari, M Ali and T Naved, 2004. New compounds from Zizyphus vulgaris. Pharmaceutical Biology, 42(7): 508-511.

[20] Omobuwajo TO, AE Akande, LA Sanni, 1999. Selected physical, mechanical and aerodynamic properties African Breadfruit (Treculiaafricana) seeds. J. Food Eng. 40: 241-244.

[21] Ozturk I, SErcisli and M Kara, 2009. Chosen physical properties of olive cultivars (Oleaeuropaea L.), Int. Agrophysics, vol. 23, pp. 309-312.

[22] Rafiee S, M KeramtJahrom, AJafari, AR Keyhani and R Mirasheh, 2006. Determination of dimension and mass of date (Deiri), In: Proceeding of the International Conference Innovations in Food and Bioprocess Technologies, Pathumthani, Thailand, December 12-14, , pp. 734-740.

[23] Razari MA, B Emadzadeh, ARafe and AA Mohammed, 2007. Physical properties of pistachio nut and its kernel as a function of moisture content and variety, J. Food Eng, 81, 209-217.

[24] Rushforth K, 1999. Trees of Britain and Europe. Collins ISBN 0-00-220013-9.

[25] Sessiz RE, O Esgile and AKizls, 2005. Moisture-dependent physical properties of caper (capparis) fruit, J. Food Eng, , 79, 1426-1431.

[26] Shepherd H and RK Bhardwaj, 1986. Moisture dependent Physical properties of pigeon pea, J. Agric. Eng.Res, 35, 227-234.

[27] Sirisomboon P, P Kitchaiya T Pholpho and W Mahuttanyavanitch, 2007. Physical and mechanical properties of Jatrophacurcas L. fruits, nuts and kernels, J. Food Eng., vol. 97, pp. 201-207.

[28] Tabatabaeefar A and A Rajabipour, 2005. Modeling the mass of apples by its geometrical attributies, ScientiaHorticulturae, , 105, 373-382.

[29] Tabatabaeefar A, 2002. Size and shape of potato tubers, Int. Agrophysics, , 16(4), 301-305.

[30] Tabatabaeefar A, 2003. Moisture-dependent physical properties of wheat. Int. Agrophysics., , 12, 207-211.

[31] Topuz A, M Topakci, M Canakci, I Akinci and F Ozdemir, 2005. Physical and nutritional properties of four orange varieties, J. Food Eng., 66, 519-523. 